\title{
The gene pool of the black apricot - Prunus dasycarpa Pers. and its use in stone fruit crops breeding
}

\author{
Gennady Eremin*, Viktor Eremin, and Taisiya Gasanova \\ Federal Research Center All-Russian Institute of Plant Genetic Resources named after N.I. Vavilov, \\ Krymsk Experiment Breeding Station - VIR Branch, 353384 Krymsk, Krasnodar Krai, Russia
}

\begin{abstract}
The article presents the results of research aimed at studying varieties, forms and hybrids of black apricot - Prunus dasycarpa Pers., preserved in the gene pool of the Krymsk EBS, VIR Branch, and identifying the feasibility of including genotypes of this species and hybrid seedlings in breeding programs to create new adaptive varieties with high fruit quality and easy vegetative reproduction of clonal rootstocks of stone fruit crops. It was revealed that cross-species hybridization of black apricot with stone fruit crops, in particular apricot and cherry plum, allows to create adaptive genotypes suitable for cultivation, as well as being a valuable source material for further breeding use. For production use, the varieties of the Krymsk EBS breeding are of interest: black apricot Kubansky Cherny (45234)*, Cherny Barkhat (45235)*, Kolibri (45240)*, Plemkot Kubansky (26217)*; Russian plum - Globus (43854)*; clonal rootstock - Alab 1 (18213)*(*VIR catalogue No.).
\end{abstract}

\section{Introduction}

To solve a number of breeding problems in the gene pool of stone fruit plants of the genus Prunus L. the genotypes of the species $P$. dasycarpa Pers are of particular interest, - black apricot, which is a hybrid between the common apricot - P. armeniaca L. and cherry plum $P$. cerasifera Ehrh. [1, 2].

Certain varieties of black apricot: Kzyl-olkhod, Tanas-Gul, Shlor-Tsiran and a number of others are known in the regions of joint growth of apricot and cherry plum, primarily in Central Asia and the Caucasus. Nevertheless, their fruits are much inferior in size and taste to the common apricot varieties, although they are valuable as raw materials for the production of various high-quality canned food.

Competitive varieties of black apricot that have become widespread have not been created either in Russia or abroad. This is primarily due to the specific, genetic characteristics of this species, due to its origin.

Krymsk EBS, VIR Branch has collected a gene pool of black apricot varieties and hybrids of apricot with cherry plum and other species of the genus Prunus in the amount of more than 50 genotypes. Nevertheless, there were no forms among them that deserve to be

\footnotetext{
* Corresponding author: kross67@mail.ru
} 
used in production. At the same time, individual species have genes of breeding-significant traits in their genomes $[3,4]$ and are of interest for use in a number of breeding programs in stone fruit crops, in particular, apricots.

The purpose of our work was to conduct research aimed at assessing the preserved genotypes of black apricot and its hybrids on the basis of adaptability, easy vegetative reproduction, high canning qualities of fruits and a number of others, and the feasibility of further inclusion of adaptive forms from among them in breeding programs for the creation of new varieties and clonal rootstocks of stone fruit crops.

\section{Materials and methods}

The research was carried out in 1995-2021 in the collection plantings of the field gene bank of the Krymsk EBS VIR Branch, located in the foothills of the northwestern part of the Main Caucasian Ridge.

In the course of many years of work, the objects of study were collection samples of the species $P$. dasycarpa Pers., preserved in the gene pool of the Krymsk EBS, as well as breeding material obtained with their participation by targeted remote hybridization or from free pollination. The research used the methods adopted in the Branch in relation to the monitoring objects [5]. The quantitative evaluation of the experimental results was carried out by the method of variance analysis [6], using the computer program Microsoft Excel 97.

\section{Results and discussion}

The black apricot genotypes and its hybrids with other species of the genus Prunus L. are used in the Krymsk EBS in breeding programs in two aspects:

- breeding of adaptive large-fruited stone fruit varieties with high taste and canning qualities of fruits;

- creation of clone rootstocks for apricot, plum, peach and almond.

The best varieties and hybrids of black apricot have inherited resistance to various biotic and abiotic stresses from cherry plum, which allows them to bear fruits more regularly than the common apricot in most regions of its cultivation. In this aspect a higher resistance to recurrent frosts at the end of winter - after the flower buds come out of the state of organic rest is especially important $[7,8]$.

In laboratory studies conducted at the Krymsk EBS in model experiments using artificial freezing, it was found that varieties of black apricot and hybrid forms created with its participation have significantly higher frost resistance of generative organs not only in the winter months, but also in early spring after provocative increases in air temperature, which is extremely important for the southern regions of fruit growing (Figure 1).

The analysis of the results of our work on the use of the most hardy varieties of the species $P$. armeniaca L. in apricot breeding for winter hardiness showed insufficient effectiveness of the use of intraspecific hybridization in the conditions of the North Caucasus. Attraction of the most frost-resistant species of this crop - Siberian apricots - $P$. sibirica L. and Manchurian apricots - P. mandshurica Maxim. gave good results in the process of breeding of apricot varieties for the Northern fruit growing zone - the Far East, Siberia and the Urals [9]. Nevertheless, due to the very short winter dormancy of flower buds and frequent freezing, these varieties were not sufficiently hardy not only in the middle zone of fruit growing, but even in the south zone. The hybrids of apricot with Chinese plum (plumcot) were also weakly resistant to low-temperature stresses and diseases, while the hybrids with low Microcerasus (Besseyi) produced small-fruited and 
insufficiently high-quality progeny and had a number of other disadvantages that made it difficult to create winter-hardy high-quality varieties $[3,10]$.

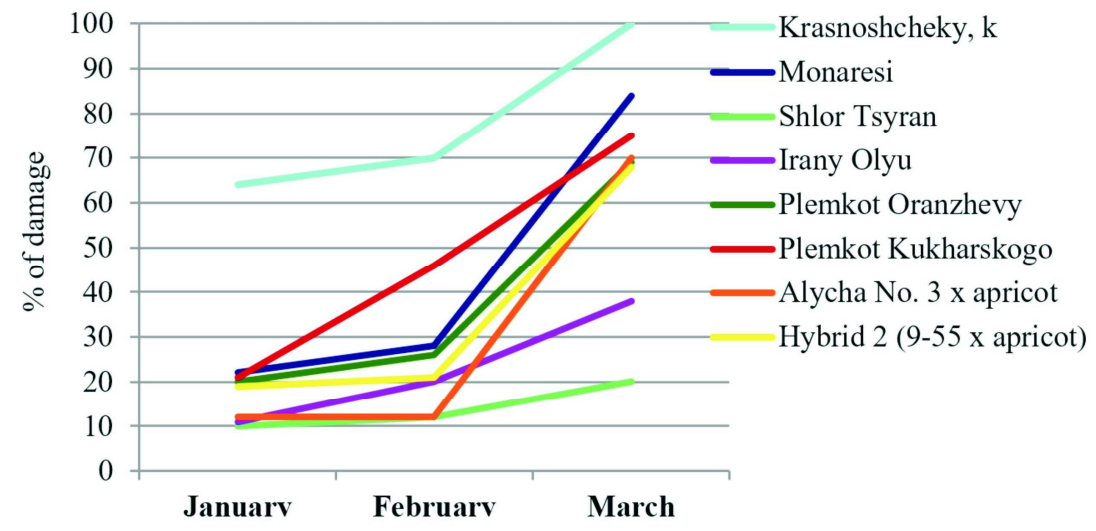

Fig. 1. Damage to flower buds of black apricot varieties and hybrids (\%) during artificial freezing at $\mathrm{t}$ $-17^{\circ} \mathrm{C}$, Krymsk EBS, VIR Branch (average for 2006-2009)

The most promising is the hybridization of apricot with cherry plum and black apricot. Among the hybrids obtained from such crosses at the Krymsk EBS, productive, adaptive and higher-quality forms were distinguished, some of which, in our opinion, can be used for cultivation.

Among these there are black apricot varieties Cherny Barkhat and Kubansky Cherny, included in the State Register of Breeding Achievements of Russia. Because of their low growth, these varieties are recommended to be cultivated in plantings using intensive technologies. They mature early and are characterized by increased winter hardiness of flower buds (Table 1).

It should be said that the common apricot is easily crossed with the cherry plum, while giving seedlings with varying degrees of manifestation of the second level of incompatibility. In $F_{1}$, some hybrids are quite fertile, but in $F_{2}$, when re-crossing with the paternal form, there is a decrease in the viability of hybrids. This is a manifestation of nucleocytoplasmic incompatibility, in which an increase in the proportion of the paternal species in the nucleus of $\mathrm{F}_{2}$ hybrids over $50 \%$ leads to complete incompatibility, which causes the hybrid death [11-12]. This circumstance makes it difficult to obtain $\mathrm{F}_{2}$ hybrids with the forms of the paternal species in case of using the cherry plum as a maternal partner and inhibits the strengthening of apricot traits in the progeny. When crossing with a representative of the mother species, the viability and productivity increases - up to normal, while pollination with cherry plum pollen (or other diploid plum species) increases the manifestation of cherry plum traits in $\mathrm{F}_{2}$ [13]. It is the manifestation of nucleocytoplasmic incompatibility that leads to the death of $F_{2}$ seedlings when sowing seeds of $F_{1}$ hybrids and black apricot varieties in the studies of a number of breeders. The pollinator in this case, apparently, for $\mathrm{F}_{1}$ hybrids was an apricot.

In the work on the breeding program for new apricot varieties, positive results were obtained from hybridization of cherry plum and Russian plum varieties with apricot, as well as when sowing seeds from free pollination of black apricot varieties. At the same time, among the hybrids of cherry plum with apricot in $\mathrm{F}_{2}$ and among the seedlings of black apricot varieties, there were no viable seedlings in the hybrids of the common apricot type, and most of the seedlings were closer to the varieties of black apricot or deviated towards the cherry plum. 
Table 1. Damage (\% of death) of flower buds of apricot varieties in different winters, Krymsk EBS, VIR Branch

\begin{tabular}{|l|c|c|c|c|}
\hline \multirow{2}{*}{ Variety name } & \multicolumn{5}{|c|}{ Freezing of flower buds, (average in \%), at t ${ }^{\circ} \mathrm{C}$} \\
\cline { 2 - 5 } & $\begin{array}{c}02.02 .2014 \\
\mathrm{t}{ }^{\circ} \mathrm{C}-21.8\end{array}$ & $\begin{array}{c}09.01 .2015 \\
\mathrm{t}{ }^{\circ} \mathrm{C}-24.0\end{array}$ & $\begin{array}{c}17.03 .2020 \\
\mathrm{t}{ }^{\circ} \mathrm{C}-7.6 \\
\text { (after thaw) }\end{array}$ & $\begin{array}{c}20.02 .2021 \\
\mathrm{t}{ }^{\circ} \mathrm{C}-9.4 \\
\text { (after thaw) }\end{array}$ \\
\hline \multicolumn{5}{|c|}{ Common apricot } \\
\hline Krasnoshcheky (k) & 89 & 100 & 58 & 96 \\
\hline \multicolumn{5}{|c|}{ Black apricot } \\
\hline Monaresi (k) & 38 & 71 & 47 & 51 \\
\hline Kubansky Cherny & 0 & 81 & 30 & 20 \\
\hline Cherny Barkhat & 0 & 69 & 29 & 38 \\
\hline Kolibri & 18 & 79 & 35 & 20 \\
\hline Plemkot Kubansky $^{\mid}$ & 0 & 86 & 26 & 39 \\
\hline LSD $_{05}$ & & 12 & 9 & 11 \\
\hline
\end{tabular}

From this type hybrids, elites were distinguished, similar in their morphological characteristics and biological indicators to the best varieties of black apricot, but also more adaptive and large-fruited (Table 2).

Table 2. Characteristics of varieties and elite seedlings of black apricot, created at the Krymsk EBS, VIR Branch

\begin{tabular}{|c|c|c|c|c|c|}
\hline Variety, elite & Origin & Date of fruit & \multicolumn{2}{|c|}{$\begin{array}{c}\text { Average } \\
\text { fruit } \\
\text { reigening }\end{array}$} & \multicolumn{2}{|c|}{$\begin{array}{c}\text { Estimated } \\
\text { score of } \\
\text { processed } \\
\text { products }\end{array}$} \\
\cline { 5 - 7 } & & juice & jam \\
\hline $\begin{array}{c}\text { Alycha } \\
\text { Obilnaya, }\end{array}$ & $\begin{array}{c}\text { Obilnaya (Berbank plum } \\
\times \text { Tavricheskaya plum }\end{array}$ & $15.07-25.07$ & $42.3 \pm 0.4$ & 4.4 & 4.3 \\
\hline $\begin{array}{c}\text { Russian plum } \\
\text { Globus }\end{array}$ & $\begin{array}{c}\text { G0d 2 (cherry plum } \times \\
\text { apricot) } \times \text { Obilnaya } \\
\text { cherry plum }\end{array}$ & $23.07-04.08$ & $60.7 \pm 0.6$ & 4.6 & 4.6 \\
\hline Hybrid 17-46-30 & Kolibri, s.o. & $05.07-15.07$ & $40.2 \pm 0.3$ & 4.6 & 4.4 \\
\hline Hybrid 17-46-92 & Plemkot Kubansky, s.o. & $01.07-15.07$ & $41.0 \pm 0.5$ & 4.4 & 4.5 \\
\hline Hybrid 17-47-4 & Cherny Barkhat, s.o. & $05.07-17.07$ & $30.2 \pm 0.4$ & 4.5 & 4.7 \\
\hline Hybrid 17-46-49 & Kubansky Cherny, s.o. & $15.07-25.07$ & $35.4 \pm 0.6$ & 4.7 & 4.5 \\
\hline $\begin{array}{c}\text { Hybrid 17-45- } \\
133\end{array}$ & Plemkot Kubansky, s.o. & $01.07-15.07$ & $40.1 \pm 0.5$ & 4.6 & 4.6 \\
\hline & LSD 0.5 & & 2.2 & & \\
\hline
\end{tabular}

Among the seedlings obtained, a yellow-fruited, hairy form is of interest: Hybrid 17-45133, isolated from seedlings of the Plemkot Kubansky from free pollination. This elite is characterized by adaptability and large fruits (up to $44 \mathrm{~g}$ ).

Among the hybrid seedlings, forms that deviated towards cherry plum and were close to the varieties of Russian plum were obtained. They do not have the fruit fluff characteristic of apricot. Elites of this type are not inferior in productivity, taste and canning qualities, the best varieties of Russian plum, and the variety Globus, included in the State Register of Breeding Achievements of the Russian Federation, surpasses all varieties of this crop in terms of fruit size, with sufficiently high taste and canning qualities.

It is very important that the variety Globus was the most productive among the varieties of Russian plum when cultivated in dense plantations using a weakly clonal rootstock 
VVA 1. This makes it particularly valuable for use in intensive-type technologies (Figure 2).

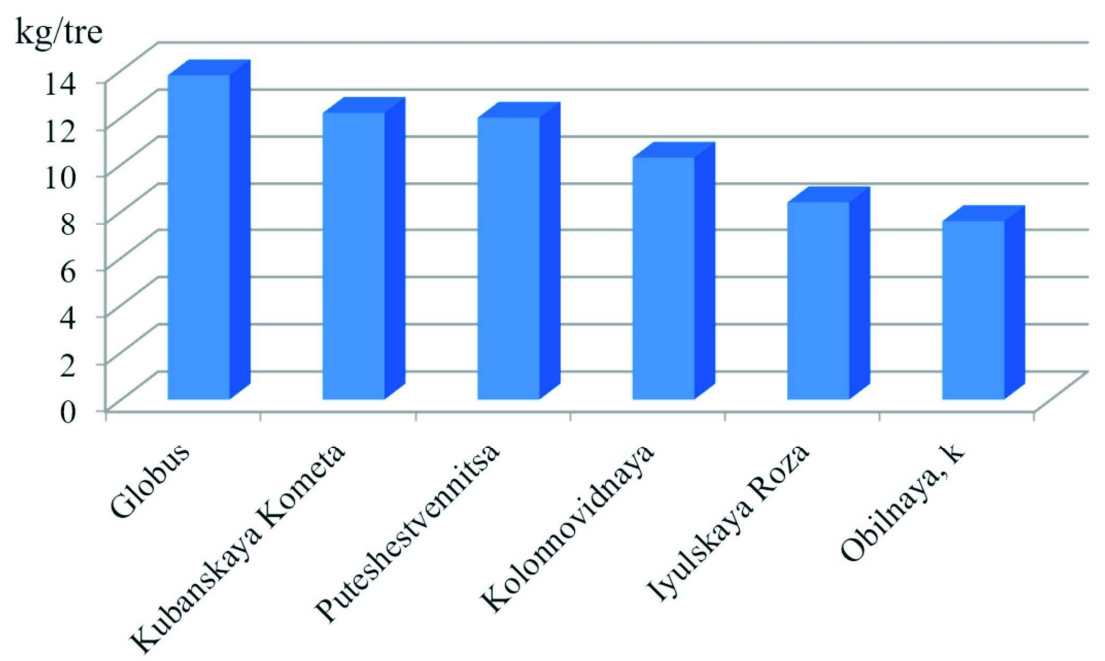

Fig. 2. Average productivity of trees of the Globus variety in comparison with other varieties of Russian plum on the VVA 1 rootstock for 2008-2009, kg/tree, Krymsk EBS, VIR Branch (year of planting 2005, planting scheme $5.0 \times 1.5 \mathrm{~m}$ )

The black apricot genotypes and its hybrids were also promising as clonal rootstocks of stone fruit crops. They successfully combine resistance to water stress with adaptability to unfavorable soil conditions and temperature changes in the winter-spring period, ease of vegetative reproduction and good compatibility with a wide range of species and varieties of plums, apricots, peaches, almonds (Table 3).

Table 3. Characteristics of clonal rootstocks bred with the participation of black apricot at the Krymsk EBS, VIR Branch

\begin{tabular}{|c|c|c|c|c|c|c|}
\hline \multirow[t]{2}{*}{ Elite } & \multirow[t]{2}{*}{ Origin } & \multirow{2}{*}{$\begin{array}{l}\text { Growth } \\
\text { power }\end{array}$} & \multicolumn{2}{|c|}{$\begin{array}{c}\text { Propagation } \\
\text { by cuttings }\end{array}$} & \multirow{2}{*}{\multicolumn{2}{|c|}{ 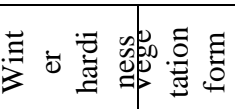 }} \\
\hline & & & & 00 & & \\
\hline AChT-1 & Black apricot $\times$ blackthorn & $\begin{array}{l}\text { half- } \\
\text { dwarf }\end{array}$ & + & + & high & weak \\
\hline $\begin{array}{l}\text { Hybrid } \\
16-12-220\end{array}$ & Black apricot $\times$ garden plum & medium & + & + & high & weak \\
\hline Kolibri & Russian plum $\times($ apricot $\times$ peach $)$ & dwarf & + & + & medium & no \\
\hline Alab 1 & $\begin{array}{l}\text { (Chinese-American plum } \times \\
\text { Cherry plum }) \times \text { apricot }\end{array}$ & medium & + & + & high & no \\
\hline
\end{tabular}

Among such clonal rootstocks, bred at the Krymsk EBS and included in the State Register of Breeding Achievements of the Russian Federation, there is the clonal rootstock Alab 1, resistant to the nematode Mesocriconema xenoplax in California [14].

In hybrid populations, when crossing apricot and cherry plum with other types of stone fruit plants, weak-growing individuals are often found, which are of simultaneous interest in breeding when breeding weak-growing clonal rootstocks and varieties for use in intensive technologies. The Kolibri variety is an example of such elites, which is currently being tested both as a dwarf rootstock and as a winter-hardy variety with sufficiently highquality fruits. 


\section{Conclusion}

1. Interspecific hybridization of black apricot with cherry plum is a promising direction in the breeding of varieties of black apricot, Russian plum and clonal rootstocks for stone fruit crops.

2. For production use, the varieties of the Krymsk EBS breeding are of interest: black apricot - Kubansky Cherny (45234)*, Cherny Barkhat, Kolibri, Plemkot Kubansky; Russian plum - Globus; clone rootstock - Alab 1.

Acknowledgment. The work was carried out on the VIR plant genetic resources collection within the framework of the state assignment according to the VIR thematic plan on the project No. 06622019-0004 "Collections of vegetatively propagated crops (potatoes, fruit, berry, ornamental, grapes) and their wild VIR relatives - study and rational use"

\section{References}

1. V.I. Tkachenko, Bull. of VNIIR n.a. N.I. Vavilov (1982)

2. N.V. Kovalev, Apricot (Moscow, Selhozizdat, 1963)

3. G. V. Eremin, Remote hybridization of stone fruit plants (1985)

4. K. U. Yilmaz, K. Gurcan, Genetic Diversity in Plants (Rijeka, Crotia, 2012)

5. N. I. Nenko, T. N. Doroshenko, T. A. Gasanova, Modern method. aspects of the organization of the breeding process in horticulture and viticulture (Krasnodar, SKZNIISiv, 2012)

6. B. A. Dospekhov, Methodology of field experience (Moscow, Agropromizdat, 1985)

7. V. M. Gorina, V. V. Korzin, N. V. Mesyats, Evaluation of new apricot cultivars introduced in Nikita botanical garden. 7 International scientific agriculture symposium "Agrosym-2016", October 6-9, Serbia (2016)

8. B. Imrak, A. Kuden, V. Yurtkulu [et.al.], Biochem. Genetics., 55 (3) (2017)

9. G. T. Kazmin, Apricot in the Far East (Khabarovsk, 1975)

10. G. V. Eremin, L. G. Semyonova, T. A. Gasanova, Physiological features of the formation of adaptability, productivity and quality of fruits in stone fruit crops in the foothill zone of the north-West Caucasus (St. Petersburg, Maykop, 2008)

11. E.P. Shoferistov, E.G. Shoferistova, Bot. Sciences, 6 (1970)

12. Z.M. Asadulaev, D.M. Anatov, R.M. Osmanov, Apricot in Dagestan, 312 (2020)

13. G.V. Eremin, T.A. Gasanova, Breeding and variety breeding of garden crops, 6(2), 19$22(201$

14. V.G. Eremin, G.V. Eremin, Proc. of the KubSAU, 4(55), 68-72 (2015) 